\title{
Lipid profile of commercial beef cuts from grazing, suckling calves
}

\author{
By Raúl R. Vera, ${ }^{{ }^{*}}$ Patti English, ${ }^{2}$ Karin Vargas $^{2}$ and Ignacio Briones ${ }^{3}$ \\ 1Departamento de Ciencias Animales, Facultad de Agronomía e Ingeniería Forestal, Pontificia \\ Universidad Católica, Casilla 6177, Santiago, Chile \\ ${ }^{2}$ Carnes Andes Sur, Parral, Chile \\ ${ }^{3}$ Fundación para la Innovación Agraria, FIA, Santiago, Chile \\ ( ${ }^{*}$ Corresponding author: rverai@uc.cl)
}

\section{RESUMEN}

Perfil lipídico de cortes comerciales de terneros lactantes en pastoreo.

El objetivo del trabajo fue determinar el contenido de grasa, colesterol y perfil de ácidos grasos de ocho cortes provenientes de terneros lactantes, de 7-8 meses de edad y engordados en prados permanentes de la VII Region de Chile, por productores pequeños. Se sacrificaron 54 animales en tres fechas diferentes de Marzo de 2008, con un peso medio de canal de $150 \pm 22 \mathrm{~kg}$. Se obtuvieron cinco muestras al azar de cada corte a medida que salían de la planta procesadora, las que fueron enfriadas y empaquetadas siguiendo el protocolo industrial. Los cortes fueron seleccionados en base a un análisis no replicado anterior de 21 cortes comúnmente disponibles en el mercado. Se encontraron diferencias significativas y considerables en el contenido de grasa, con una media de $2,12 \%$ y rango de 4,23 para lomo liso y $0,68 \%$ para asado abastero. El contenido medio de colesterol fue de 44,7 mg/100 g de carne, sin diferencias significativas entre cortes. Un análisis discriminante exigente detectó diferencias altamente significativas en el perfil de ácidos grasos, y clasificó correctamente a 37 de las 40 muestras analizadas. La relación n6:n3 no difirió entre cortes y osciló entre 1,9 para lomo liso y 2,6 para sobrecostilla y punta de ganso respectivamente. Se encontraron diferencias significativas para la mayoría de los ácidos grasos y para el índice de aterogenicidad. Sin embargo este último osciló sólo entre 0,60 y 1,07 para posta negra y lomo liso respectivamente. Los resultados son comparados con valores informados en la literatura. A pesar de las diferencias halladas entre cortes, todos fueron magros y tuvieron perfiles lipídicos compatibles con la salud humana, en dietas balanceadas.

PALABRAS CLAVE: Ácidos grasos - Cortes de carne Lípidos - Terneros.

\section{SUMMARY}

Lipid profile of commercial beef cuts from grazing, suckling calves.

The objective of the present research was to determine the contents of fat, cholesterol and fatty acids of eight beef cuts from unsupplemented, suckling, 7-8 month old male and female calves reared on permanent pastures in the VIlth Region of Chile by small cattle producers. A total of 54 animals with a mean carcass weight of $150+22 \mathrm{~kg}$ were slaughtered in a commercial abattoir on three different dates during the month of March, 2008. Five samples of each of eight cuts were collected at random as they exited the abattoir, cooled and packed following industry practices.
Beef cuts were selected based on an earlier, unreplicated analysis of 21 common cuts, to represent a wide range of cuts currently available to consumers. Large and significant differences were observed in fat content with a mean of $2.12 \%$, ranging between $4.23 \%$ for sirloin strip and $0.68 \%$ for butcher's roast. The cholesterol content did not differ between cuts (mean $44.7 \mathrm{mg} / 100 \mathrm{mg}$ meat) and was unrelated to fat percentage. A stringent discriminant analysis of the fatty acid profiles detected highly significant differences between cuts and correctly classified 37 of the 40 samples. The n6:n3 ratio did not differ between cuts and ranged between 1.9 for sirloin strip and 2.6 for rib roast and silverside's end. Significant differences between cuts were detected for most fatty acids, and for the atherogenicity index. Nevertheless, the latter only varied between 0.60 and 1.07 for topside and sirloin strip respectively. The results are compared with literature values. Notwithstanding differences between cuts, all beef samples were lean and had lipid profiles compatible with human health as part of a balanced diet. profile.

KEY-WORDS: Beef cuts - Calves - Fatty acid - Lipid

\section{INTRODUCTION}

Consumers are increasingly aware of the relationship between nutrition and health, and this knowledge has led to reservations regarding the consumption of red meats associated with the content and quality of fat, although the lipid content of meat contributes to its cooking characteristics, palatability and overall organoleptic properties (Wood et al., 2008). Nevertheless, the lipid composition of red meats, and beef in particular, can vary considerably depending on the feeding strategy and production system employed (Kraft et al., 2008; Rearte, 2002). It has been shown that beef lipids can be manipulated by altering, among others, the content of saturated (SFA), and polyunsaturated fatty acids (PUFA), the n3: n6 ratio, and the content of conjugated linoleic acid (CLA) as well as that of its precursors (Scollan et al., 2006). Advancements in beef lipid analyses are due in part to the development and refinement of the analytical techniques used in determining the fatty acid profiles of feed and food (e.g. Christie et al., 2007; Christie, 1989). 
A literature search conducted on the database of the INIA Library at La Platina, Chile, using the keywords (in Spanish) "meat + fatty + acids" identified only 33 Chilean references over the period from 1960-2008. Only 10 of them referred to beef, all of them prior to 1990, and with some overlap between theses and papers. In contrast, research conducted in neighboring countries is comparatively abundant and up-to-date (e.g. Garibotto and Bianchi Olascoaga, 2008) and sometimes includes comparisons among important beef cuts.

An exploratory, unreplicated, analysis of 21 beef cuts conducted by Vera et al. (2009) revealed large differences in their lipid content and composition, but also showed that all of them were lean, and that from a human health perspective had adequate fatty acid profiles.

The objective of the present research was to compare the lipid composition of eight different cuts of beef from calves produced by small farmers in the VIlth Region of Chile.

\section{MATERIALS AND METHODS}

The experimental animals were suckling male and female calves grazing year round with their dams on mixed pastures, without access to concentrate or supplements. The calves where shipped to a commercial abattoir without prior weaning at the age of 7-8 months. A total of 54 Hereford, Aberdeen Angus and crossbred calves fattened by small farmers associated with Carnes Andes Sur (VIIth Region of Chile; latitude: $33^{\circ} 24^{\prime}$, longitude: $70^{\circ} 40^{\prime} \mathrm{W}$ ) were slaughtered on three different dates in March, 2008. The calves originated from 11 different farms and their average carcass weight was $150 \pm 22 \mathrm{~kg}$. Five samples of eight commercial beef cuts each selected based on earlier information (Vera et al., 2009) were collected randomly as they came out of the abattoir so that each sample and cut may have originated from a different animal. It was therefore expected that variation within- and between cuts would be maximized. All samples were cooled and later vacuum packed following industry practices. The beef samples were subjected to chemical analysis as they would be presented to the final consumer, without removing the external fat cover if any. Thus, the analytical results represent the lipid content of muscle, including intramuscular fat, and the undetermined amount of cover fat left by processing in the abattoir.

All chemical analyses were conducted at the Departamento de Ciencia y Tecnología de los Alimentos, Facultad Tecnológica, Universidad de Santiago de Chile, and included the determination of total fat, cholesterol and the fatty acid profile. Fatty acids were extracted as per Bligh and Dyer (1959), and were methylated with BF3 (Christie, 1989). Quantification was carried out by gas chromatography using a $60 \mathrm{~m} \times 0.22 \mathrm{~mm} \times 0.25$ $\mu \mathrm{m}$ BPX-70 column with C17:0 as internal marker. The procedure quantified 21 fatty acids, but 13 individual points were missing in the 5 samples $\times 8$ cuts $\times 21$ fatty acids database, including 8 for two trans fatty acids (TFA) and the rest were minor PUFA. The results were expressed as percentages of each fatty acid relative to the total sum, various ratios among them, including the atherogenicity index (Ulbricht and Southgate, 1991), as well as the actual content of each fatty acid ( $\mathrm{g} / 100 \mathrm{~g}$ meat).

Cholesterol was determined by reverse-phase HPLC with a UV-VIS detector after the extraction of fat (Bligh and Dyer, 1959) and unsaponifiable material (AOAC, 2005).

Prior to statistical analysis, the database was examined for internal consistency and the possible presence of outliers. The distribution of the data for individual fatty acids was examined and if not normally distributed, the data were subject to appropriate transformations. A multivariate analysis of variance was initially conducted on the fatty acids vector, which was followed by a univariate analysis of individual fatty acids (\% of total fatty acids) and selected ratios among them. The contents of fatty acids (mg/100 g meat) were not statistically analyzed as they can be approximated by multiplying the respective percentages by the fat content, since the sum of the fatty acids identified in the chromatograms averaged $96 \%$ of the fat content. The discriminant analysis used a forward stepwise procedure to select variables, with $F=4$ for acceptance and rejection. All statistical analyses were carried out with STATGRAPHICHS Plus 5.1 ${ }^{\circledR}$.

\section{RESULTS}

There was considerable variation between cuts in fat content $(p<0.01$, Table 2), with an average content of $2.12 \%$ and maximum and minimum for "lomo liso" (the approximate USA and UK synonyms are listed in Table 1) and "asado abastero" whose values were $4.23 \%$ and $0.68 \%$ respectively. On the other hand, no significant differences $(p>0.05)$ were found between cuts for cholesterol content, which averaged $44.7 \mathrm{mg} / 100 \mathrm{~g}$ meat (range 33.2-58.8). The correlation between fat $\%$ and cholesterol content was not significant $(p>0.05)$.

The discriminant analysis conducted on the vector of 18 fatty acids for which there were complete data for all cuts identified five discriminant functions. The Wilks Lambda test was highly significant $(p<0,01)$ for the first four functions and the respective standardized coefficients are shown in Table 4. The discriminant functions correctly classified all but two "abastero" and one "posta negra" samples.

The contribution of each fatty acid to the total is shown in Table 1. As can be inferred from the generally low standard errors (s.e.) there was very little variation for the fatty acid profile within cuts (Table 1), which probably contributed to highly 
Table 1

Fatty acids (\% of total fatty acids) of eight Chilean beef cuts with their approximate USA/UK synonyms

\begin{tabular}{|c|c|c|c|c|c|c|c|c|c|c|c|}
\hline $\begin{array}{c}\text { Chile } \\
\text { USA/UK }\end{array}$ & $\begin{array}{c}\text { Asado } \\
\text { carnicero } \\
\text { butcher's } \\
\text { roast }\end{array}$ & $\begin{array}{l}\text { Punta } \\
\text { de ganso } \\
\text { silverside's } \\
\text { end }\end{array}$ & $\begin{array}{c}\text { Abastero } \\
\text { leg of } \\
\text { shank }\end{array}$ & $\begin{array}{l}\text { Lomo } \\
\text { liso } \\
\text { sirloin } \\
\text { strip }\end{array}$ & $\begin{array}{l}\text { Plateada } \\
\text { rib cap }\end{array}$ & $\begin{array}{l}\text { Posta } \\
\text { negra } \\
\text { topside }\end{array}$ & $\begin{array}{c}\text { Sobre- } \\
\text { costilla } \\
\text { square } \\
\text { chuck; rib } \\
\text { roast }\end{array}$ & $\begin{array}{l}\text { Posta } \\
\text { paleta } \\
\text { shoulder } \\
\text { clod }\end{array}$ & Means & s.e. & $\mathbf{p}<$ \\
\hline C12:0 & $0.44 a b$ & $0.48 a b$ & $0.48 a b$ & $1.10 \mathrm{~d}$ & $0.58 \mathrm{bc}$ & $0.42 a b$ & $0.74 \mathrm{c}$ & $0.30 \mathrm{a}$ & 0.57 & 0.07 & 0.0001 \\
\hline C14:0 & 6.82 b & $8.00 \mathrm{~cd}$ & $5.54 \mathrm{a}$ & $9.88 \mathrm{e}$ & $7.40 \mathrm{~cd}$ & $5.12 \mathrm{a}$ & $8.88 \mathrm{~d}$ & $5.64 \mathrm{a}$ & 7.16 & 0.31 & 0.00001 \\
\hline C14:1 & 2.18 & 2.30 & 2.50 & 2.28 & 1.84 & 2.28 & 2.38 & 2.30 & 2.27 & 0.17 & N.S. \\
\hline C15:0 & $1.04 \mathrm{c}$ & $0.64 \mathrm{a}$ & $1.02 \mathrm{c}$ & $0.8 a b$ & $0.98 \mathrm{bc}$ & $0.88 \mathrm{bc}$ & 0.92 bc & $1.00 \mathrm{bc}$ & 0.91 & 0.08 & 0.01 \\
\hline C16:0 & $27.02 \mathrm{a}$ & $30.5 \mathrm{bc}$ & $25.96 \mathrm{a}$ & $31.66 \mathrm{c}$ & $32.14 \mathrm{c}$ & $25.8 \mathrm{a}$ & $29.7 b$ & 25.9 a & 28.57 & 0.63 & 0.00001 \\
\hline C16:1 & $5.16 \mathrm{c}$ & $5.28 \mathrm{c}$ & $3.56 \mathrm{a}$ & $4.5 \mathrm{~b}$ & $4.48 \mathrm{~b}$ & $3.36 \mathrm{a}$ & $3.82 \mathrm{a}$ & $4.01 \mathrm{a}$ & 4.22 & 0.19 & 0.0001 \\
\hline $\mathrm{C} 16: 1 \mathrm{t}$ & .14 & & 0.20 & 0.13 & 0.16 & 0.20 & 0.16 & 0.29 & 0.16 & 0.04 & N.S. \\
\hline C17:0 & 0.88 & 0.78 & & 0.78 & 0.80 & 0.94 & 0.74 & 1.20 & 0.85 & 0.08 & N.S. \\
\hline C18:0 & $13.62 \mathrm{c}$ & $11.56 a b$ & $12.3 b$ & $11.32 a b$ & $11.2 a b$ & $11.78 a b$ & 10.62 a & 11.8 bc & 11.84 & 0.45 & 0.002 \\
\hline C18:1 & $34.56 \mathrm{e}$ & $30.42 \mathrm{a}$ & $30.42 \mathrm{a}$ & $30.76 \mathrm{ab}$ & $32.24 \mathrm{~cd}$ & $32.16 \mathrm{~b}$ & $31.24 \mathrm{ab}$ & 35.2 de & 31.94 & 0.55 & 0.00001 \\
\hline C18:1t & $0.38 a b$ & $0.46 \mathrm{~b}$ & $0.38 a b$ & $0.78 \mathrm{c}$ & $0.44 b$ & $0.28 \mathrm{a}$ & $0.26 \mathrm{a}$ & $0.29 a b$ & 0.42 & 0.05 & 0.001 \\
\hline C18:2 n6 & $3.16 a b$ & $5.08 \mathrm{c}$ & $7.98 \mathrm{e}$ & $2.68 \mathrm{a}$ & $3.40 \mathrm{~b}$ & $8.22 \mathrm{e}$ & $5.30 \mathrm{c}$ & $6.70 \mathrm{~d}$ & 5.61 & 0.21 & 0.00001 \\
\hline C18:3 n3 & $1.08 \mathrm{a}$ & $1.38 a b$ & $2.44 \mathrm{c}$ & $1.08 \mathrm{a}$ & $1.32 a b$ & $2.78 \mathrm{C}$ & $1.56 \mathrm{~b}$ & $1.60 \mathrm{~b}$ & 1.66 & 0.12 & 0.00001 \\
\hline C20:0 & 0.36 cde & $0.18 \mathrm{a}$ & $0.24 a b$ & $0.44 \mathrm{e}$ & $0.24 a b$ & $0.26 \mathrm{abc}$ & $0.40 \mathrm{de}$ & $0.20 \mathrm{a}$ & 0.29 & 0.05 & 0.01 \\
\hline C20:1 n9 & $0.36 \mathrm{a}$ & $0.44 \mathrm{a}$ & $0.36 \mathrm{a}$ & $0.28 \mathrm{a}$ & $0.34 \mathrm{a}$ & $0.32 \mathrm{a}$ & $0.74 \mathrm{~b}$ & $0.20 \mathrm{a}$ & 0.41 & 0.09 & 0.02 \\
\hline C20:3 n3 & $0.18 a b$ & $0.28 \mathrm{bc}$ & $0.86 f$ & $0.13 a$ & $0.14 \mathrm{a}$ & $0.68 \mathrm{e}$ & $0.32 \mathrm{c}$ & $0.50 \mathrm{~d}$ & 0.39 & 0.04 & 0.0001 \\
\hline C20:3 n6 & $0.50 \mathrm{c}$ & $0.40 \mathrm{bc}$ & $0.88 d$ & $0.18 \mathrm{a}$ & $0.28 a b$ & $0.82 \mathrm{~d}$ & $0.26 a b$ & $0.78 \mathrm{~d}$ & 0.52 & 0.07 & 0.0001 \\
\hline C20:4 n6 & $1.06 \mathrm{bc}$ & $0.86 a b$ & $1.70 \mathrm{~d}$ & $0.72 \mathrm{a}$ & $0.96 a b$ & $1.68 \mathrm{~d}$ & $0.96 a b$ & $1.18 \mathrm{c}$ & 1.14 & 0.09 & 0.0001 \\
\hline C20:5 n3 & $0.26 \mathrm{a}$ & $0.28 \mathrm{a}$ & $0.88 \mathrm{c}$ & $0.22 \mathrm{a}$ & $0.36 \mathrm{a}$ & $0.86 \mathrm{c}$ & $0.36 \mathrm{a}$ & $0.70 \mathrm{~b}$ & 0.47 & 0.05 & 0.001 \\
\hline C22:6 n3 & 0.22 & 0.16 & 0.24 & 0.26 & 0.26 & 0.18 & 0.18 & 0.10 & 0.21 & 0.04 & N.S. \\
\hline C22:5 n3 & $0.58 \mathrm{~cd}$ & $0.34 a b$ & $1.08 \mathrm{f}$ & $0.17 \mathrm{a}$ & $0.44 \mathrm{bc}$ & 0.98 ef & $0.44 \mathrm{bc}$ & $0.78 \mathrm{de}$ & 0.62 & 0.07 & 0.0001 \\
\hline
\end{tabular}

Horizontal means followed by the same letter do not differ significantly $(p>0.05)$; .s.e. $=$ standard error of the mean,

$\mathrm{n}=5$ for individual means.

significant differences between cuts for most fatty acids even if absolute differences were modest. SFA accounted for $56 \%$ ("lomo liso") to $45 \%$ ("posta negra") of the total fatty acids (Table 2) and in general SFA tended to increase with increasing fat percentage $(r=0.60, p<0.01)$. On average, stearic acid (C18:0) accounted for one fifth of the SFA, and oleic acid represented $80 \%$ of the total MUFA. Generally speaking, beef cuts with the larger content of SFA had a non significantly $(p>0.05)$ lower content of monounsaturated fatty acids (MFA) and particularly a lower PUFA content $(r=-0.88$, $\mathrm{p}<0.01)$. Also, palmitic acid $(\mathrm{C} 16: 0)$, the main SFA, tended to increase with increasing fat $\%$ across cuts.
The magnitude of the differences between cuts in fatty acid composition was slightly higher when expressed as percentages than in terms of the actual content shown in Table 3. As an example, "posta negra" trebles the PUFA\% of "lomo liso", but the actual difference in content is smaller, a trend that is applicable to most of the remaining fatty acids. The PUFA/SFA ratio varied between cuts $(p<0.01$, Table 2) and ranged between 0.1 for "lomo liso" and 0.35 for "abastero" and "posta negra". The PUFA/SFA decreased asymptotically across cuts with increasing fat $\%$ as shown in Figure 1. The n6: $n 3$ ratio (Table 2) was somewhat variable within and between cuts, and would have reached significance at $p<0.06$;

Table 2

Fat, saturated (SFA), monounsaturated (MUFA), polyunsaturated (PUFA) and trans fatty acids, PUFA/SFA ratio and the n6:n3 ratio of eight Chilean beef cuts

\begin{tabular}{|c|c|c|c|c|c|c|c|c|c|c|c|}
\hline & $\begin{array}{l}\text { Asado } \\
\text { carnicero }\end{array}$ & $\begin{array}{l}\text { Punta de } \\
\text { ganso }\end{array}$ & Abastero & $\begin{array}{l}\text { Lomo } \\
\text { liso }\end{array}$ & Plateada & $\begin{array}{l}\text { Posta } \\
\text { negra }\end{array}$ & $\begin{array}{l}\text { Sobre- } \\
\text { costilla }\end{array}$ & $\begin{array}{l}\text { Posta } \\
\text { paleta }\end{array}$ & Means & s.e. & $\mathbf{p}<$ \\
\hline Fat, \% & $2.35 \mathrm{bcd}$ & $2.56 \mathrm{~cd}$ & $0.68 \mathrm{a}$ & $4.23 \mathrm{e}$ & $3.39 \mathrm{de}$ & $1.18 a b$ & $1.25 a b$ & $1.32 \mathrm{abc}$ & 2.12 & 0.44 & 0.0001 \\
\hline SFA, \% & 50.2 b & $52.1 \mathrm{c}$ & $46.5 \mathrm{a}$ & $56.0 \mathrm{~d}$ & $53.3 \mathrm{c}$ & $45.2 \mathrm{a}$ & $52.0 \mathrm{c}$ & $46.4 \mathrm{a}$ & 50.2 & 0.55 & 0.001 \\
\hline MUFA, \% & $42.3 d$ & $38.4 \mathrm{~b}$ & $36.8 \mathrm{a}$ & $37.8 a b$ & 38.9 bc & $38.1 \mathrm{ab}$ & $38.2 a b$ & $40.2 \mathrm{c}$ & 38.8 & 0.51 & 0.001 \\
\hline PUFA, \% & $7.0 \mathrm{~b}$ & $8.8 c$ & $16.1 \mathrm{e}$ & $5.3 \mathrm{a}$ & $7.2 \mathrm{~b}$ & $16.2 \mathrm{e}$ & $9.4 \mathrm{c}$ & $12.8 \mathrm{~d}$ & 10.3 & 0.30 & 0.001 \\
\hline Trans, \% & $0.52 a b$ & $0.58 a b$ & $0.58 a b$ & $0.86 \mathrm{c}$ & $0.6 \mathrm{~b}$ & $0.48 a b$ & $0.42 \mathrm{a}$ & n.d. & 0.57 & 0.06 & 0.05 \\
\hline PUFA/SFA & $0.14 \mathrm{~b}$ & $0.17 \mathrm{c}$ & $0.35 \mathrm{e}$ & $0.10 \mathrm{a}$ & $0.14 b$ & $0.36 \mathrm{e}$ & $0.180 \mathrm{c}$ & $0.28 d$ & 0.21 & 0.007 & 0.001 \\
\hline n6: n3 & 2.10 & 2.60 & 1.90 & 1.90 & 1.90 & 2.00 & 2.50 & 2.40 & 2.17 & 0.23 & N.S. \\
\hline index & $0.72 \mathrm{~b}$ & $0.86 \mathrm{c}$ & $0.63 \mathrm{a}$ & $1.07 \mathrm{~d}$ & $0.91 \mathrm{c}$ & $0.60 \mathrm{a}$ & $0.87 c$ & $0.62 \mathrm{a}$ & 0.79 & 0.03 & 0.01 \\
\hline
\end{tabular}

Horizontal means followed by the same letters do not differ significantly $(p>0.05)$. s.e.=standard error of the mean;

$n=5$ for individual means except for trans fatty acids; $n . d$. not determined. 
Table 3

Fatty acid content of eight beef cuts (g/100 g meat)

\begin{tabular}{lccccccccc}
\hline & $\begin{array}{c}\text { Asado } \\
\text { carnicero }\end{array}$ & $\begin{array}{c}\text { Punta } \\
\text { ganso }\end{array}$ & Abastero & $\begin{array}{c}\text { Lomo } \\
\text { liso }\end{array}$ & Plateada & $\begin{array}{c}\text { Posta } \\
\text { negra }\end{array}$ & $\begin{array}{c}\text { Sobre } \\
\text { costilla }\end{array}$ & $\begin{array}{c}\text { Posta } \\
\text { paleta }\end{array}$ & Means \\
\hline C12:0 & 0.010 & 0.012 & 0.003 & 0.044 & 0.020 & 0.004 & 0.009 & 0.005 & 0.013 \\
C14:0 & 0.152 & 0.201 & 0.035 & 0.410 & 0.240 & 0.061 & 0.106 & 0.071 & 0.159 \\
C15:0 & 0.024 & 0.068 & 0.006 & 0.030 & 0.031 & 0.009 & 0.011 & 0.013 & 0.024 \\
C16:0 & 0.619 & 0.764 & 0.162 & 1.300 & 1.062 & 0.284 & 0.355 & 0.322 & 0.608 \\
C17:0 & 0.021 & 0.020 & 0.006 & 0.031 & 0.026 & 0.011 & 0.009 & 0.013 & 0.017 \\
C18:0 & 0.315 & 0.286 & 0.077 & 0.475 & 0.364 & 0.130 & 0.127 & 0.157 & 0.241 \\
C20:0 & 0.009 & 0.005 & 0.001 & 0.016 & 0.008 & 0.003 & 0.005 & 0.003 & 0.006 \\
SFA & 1.155 & 1.304 & 0.290 & 2.305 & 1.751 & 0.501 & 0.621 & 0.583 & 1.064 \\
C14:1 & 0.051 & 0.058 & 0.016 & 0.092 & 0.063 & 0.028 & 0.028 & 0.029 & 0.046 \\
C16:1 & 0.116 & 0.133 & 0.022 & 0.185 & 0.146 & 0.039 & 0.046 & 0.044 & 0.091 \\
C18:1 & 0.792 & 0.759 & 0.190 & 1.283 & 1.072 & 0.360 & 0.372 & 0.428 & 0.657 \\
C20:1 n9 & 0.008 & 0.013 & 0.002 & 0.011 & 0.011 & 0.003 & 0.009 & 0.005 & 0.008 \\
MUFA & 0.967 & 0.963 & 0.229 & 1.570 & 1.292 & 0.429 & 0.455 & 0.506 & 0.802 \\
C18:2 n6 & 0.071 & 0.124 & 0.049 & 0.108 & 0.115 & 0.094 & 0.063 & 0.088 & 0.089 \\
C18:3 n3 & 0.026 & 0.035 & 0.015 & 0.046 & 0.044 & 0.031 & 0.019 & 0.021 & 0.030 \\
C20:3 n3 & 0.004 & 0.007 & 0.005 & 0.005 & 0.004 & 0.008 & 0.004 & 0.006 & 0.005 \\
C20:3 n6 & 0.011 & 0.009 & 0.005 & 0.007 & 0.009 & 0.010 & 0.003 & 0.010 & 0.008 \\
C20:4 n6 & 0.025 & 0.024 & 0.011 & 0.028 & 0.032 & 0.018 & 0.012 & 0.016 & 0.021 \\
C20:5 n3 & 0.006 & 0.007 & 0.006 & 0.010 & 0.012 & 0.009 & 0.004 & 0.008 & 0.008 \\
C22:5 n3 & 0.015 & 0.008 & 0.007 & 0.009 & 0.015 & 0.011 & 0.005 & 0.009 & 0.010 \\
C22:6 n3 & 0.006 & 0.004 & 0.002 & 0.012 & 0.010 & 0.002 & 0.002 & 0.003 & 0.005 \\
PUFA & 0.164 & 0.217 & 0.099 & 0.219 & 0.240 & 0.182 & 0.112 & 0.162 & 0.175 \\
C16:1 t & 0.003 & 0.003 & 0.001 & 0.004 & 0.005 & 0.002 & 0.002 & 0.003 & 0.003 \\
C18:1 t & 0.009 & 0.011 & 0.003 & 0.033 & 0.015 & 0.003 & 0.003 & 0.006 & 0.010 \\
TRANS & 0.011 & 0.032 & 0.004 & 0.035 & 0.020 & 0.005 & 0.005 & 0.009 & 0.015 \\
\hline
\end{tabular}

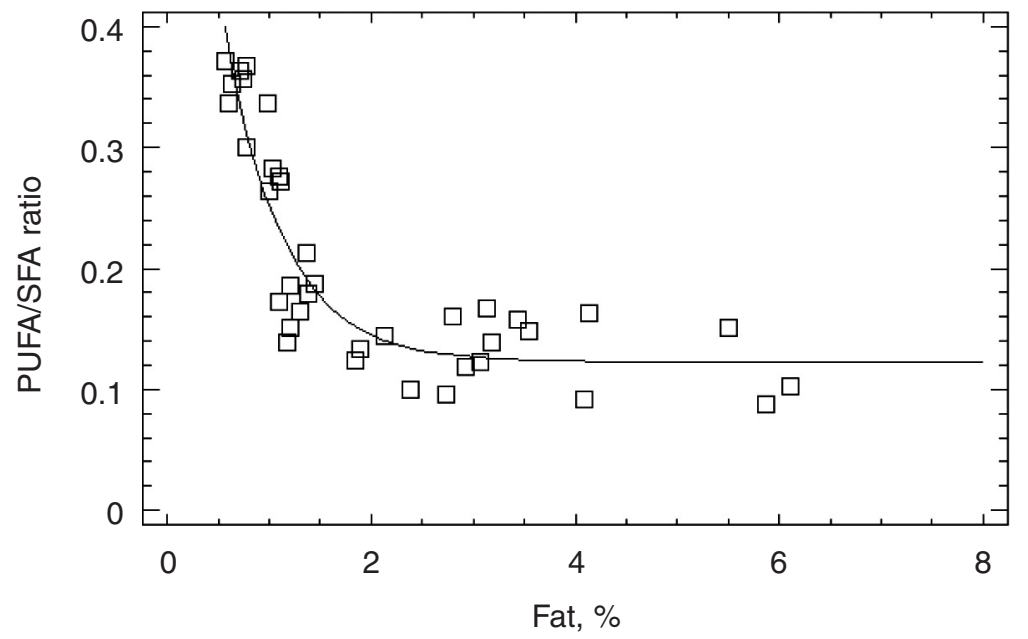

Figure 1

Plot of the PUFA/SFA ratio against Fat, \% across all samples and cuts. PUFA/SFA $=0.1228+0.7488$ exp $(-1.7605 *$ Fat, $\%)$, adjusted $r^{2}=0.83, p<.001$, s.e of the mean $=0.03790$.

nevertheless, the average values ranged only between 1.9 for "lomo liso" and 2.6 for "sobrecostilla" and "punta de ganso" respectively. Differences between cuts in the atherogenicity index were significant $(p<0.001$, Table 2$)$, with an average value of 1.2 (range 1.68-0.86). The percentage of trans fatty acids was small in all cases (Table 2).

\section{DISCUSSION}

It was initially hypothesized that variability between- and within-cuts would be maximized by the sampling procedure followed but the results were more consistent and less variable than anticipated considering the diverse provenance of the animals, the fact that they were processed on three different dates, and that they were slaughtered in a commercial abattoir following ordinary industry protocols. The small variability observed was no doubt partially responsible for finding significant differences, although they were generally small in magnitude. The small variability must also have contributed to the discriminatory power of the multivariate analysis which was effective in correctly classifying all but three of the 
40 samples as belonging to the respective cuts. Thus all eight cuts examined had distinct fatty acid profiles as shown by the multivariate analysis, and differences among them as identified by the discriminant analysis appeared to reside in a small number of fatty acids (Table 4), some of which make a small contribution to the total. Nevertheless, this hypothesis remains to be validated with a much larger and diverse database. A less stringent analysis (not shown) correctly classified all 40 samples using a larger number of variables. Multivariate techniques such as discriminant analysis and principal component analysis have been proposed as useful techniques that may assist in assuring the trace ability and quality control of various animal products (Poveda and Cabezas, 2006; Prache et al., 2005; Boyazoglu and Morand-Fehr, 2001; Reid et al., 2006; Aurousseau et al., 2007).

The fat content of all cuts was low to moderate compared to beef produced in temperate and subtropical grazing systems of neighboring countries (Latimori et al., 2005; Descalzo et al., 2005; Montossi et al., 2008; Grompone, 2008; Garibotto and Bianchi Olascoaga, 2008), Australia (Williams, 2007) and elsewhere, admittedly with somewhat older steers. Brito (2008) compared the L. dorsi of Uruguayan 2 and 3 year old steers with equivalent animals from Germany, Spain and the UK and found PUFA/SFA ratios of $0.30,0.23,0.17$, 0.43 and 0.16 respectively, whereas the present results range between 0.095 and 0.359 depending upon the cut, with the higher, more desirable, ratios generally associated with leaner cuts.

As anticipated, all of the cuts examined were leaner than those produced from older, fatter grazing cattle, frequently supplemented with concentrates. Scollan et al. (2005) have shown that SFA and MUFA increase more rapidly than PUFA with increasing age and fatness of animals, with the result that the PUFA/SFA ratio decreases exponentially with increasing carcass fat approaching a minimum around 0.1. For example, Enser et al. (1996) analyzed 50 samples of "lomo liso" (sirloin steak) collected from supermarkets in the UK and found an average of $3.84 \mathrm{~g}$ fatty acids $/ 100 \mathrm{~g}$ muscle, but $15.5 \%$ in the whole cut. Similarly, these authors reported a PUFA/SFA ratio of 0.11 in muscle and 0.05 in the adipose tissue of the cuts, and an n6:n3 ratio of 2.1 (2.3 in adipose tissue). Furthermore, as Figure 1 shows, the asymptotic decrease in the PUFA/SFA ratio referred to above, also applies across muscles. The values found in the present analyses compare favorably with the previously cited values, although a strict comparison is impossible due to differences associated with the extent to which external fat is trimmed prior to reaching the consumer. Also, the different fatty acid profiles of external or subcutanenous fat and that of intramuscular fat, particularly in regards to long-chain PUFA (Wood et al., 2008), muddle precise comparisons.

There is little information in the current literature on the composition of beef from young calves in good condition, and relevant data are included in Table 5 for comparative purposes. Villareal et al. (2005) analyzed the L. dorsi muscle of weaned, 167 $\mathrm{kg}$ calves of different biotypes in Argentina and reported an average content of $49.3 \%$ SFA, $40.2 \%$ MUFA and $10.5 \%$ PUFA. European Union regulations classify animals younger than 10 months of age as calves, and although suckling would be expected to be associated with differences in the lipid profile of meat, an early study (Moreno, cited by Moreno et al., 2006) found little differences in organoleptic characteristics between weaned and unweaned calves. Nevertheless, Sañudo et al. (1998) reported better organoleptic traits in milk-fed lambs and some differences in lipid profile. More recently, Moreno et al. (2006) compared weaned and unweaned beef calves of the Rubia Gallega breed slaughtered with a carcass weight of $184 \mathrm{kgs}$. The percentage of oleic acid in the $\mathrm{L}$. thoracis muscle of unweaned calves exceeded that of palmitic acid, and the PUFA/SFA ratio was 0.20 . In general these results, and the contents and percentages of SFA, MUFA, PUFA and major fatty acids, compared reasonably well with the composition observed for "lomo liso" in the present report.

The content and the contribution of oleic acid (C18:1) to the fatty acid profile in all the cuts examined was high and was generally higher than that of palmitic acid (C16:0), by far the main SFA, which together with $\mathrm{C} 12: 0$ and $\mathrm{C} 14: 0$ have been implicated in the course of various chronic diseases (Lichtenstein, 2006; Pacheco et al., 2006). Oleic acid is synthesized in animal tissues from stearic acid by the enzyme stearoyl CoA desaturase, the same enzyme that gives rise to CLA (Wood et al.,

Table 4

Standardized coefficients of discriminant functions

\begin{tabular}{lccrrr}
\hline & \multicolumn{5}{c}{ Function No. } \\
& $\mathbf{1}$ & $\mathbf{2}$ & $\mathbf{3}$ & $\mathbf{4}$ & \multicolumn{1}{c}{$\mathbf{5}$} \\
\hline $\mathrm{C} 14: 0$ & -0.4644 & 0.7209 & -0.2858 & -0.3834 & -0.3448 \\
$\mathrm{C} 16: 0$ & -0.3165 & 0.5012 & 0.5371 & 0.7191 & 0.1346 \\
$\mathrm{C} 16: 1$ & -0.1735 & -0.2053 & 0.9663 & -0.0946 & -0.4010 \\
$\mathrm{C} 18: 2 \mathrm{n6}$ & 0.7294 & 0.5164 & 0.5017 & -0.1499 & 0.1165 \\
C20:5 n3 & 0.6556 & -0.1375 & -0.3362 & 0.3807 & -0.6633 \\
Variance accounted for, \% & 88.73 & 6.15 & 3.5 & 1.39 & \multicolumn{1}{c}{0.23} \\
\hline
\end{tabular}


Table 5

Lipid composition of beef cuts and muscles reported in selected references. Equivalent names of beef cuts and muscles are included in parentheses

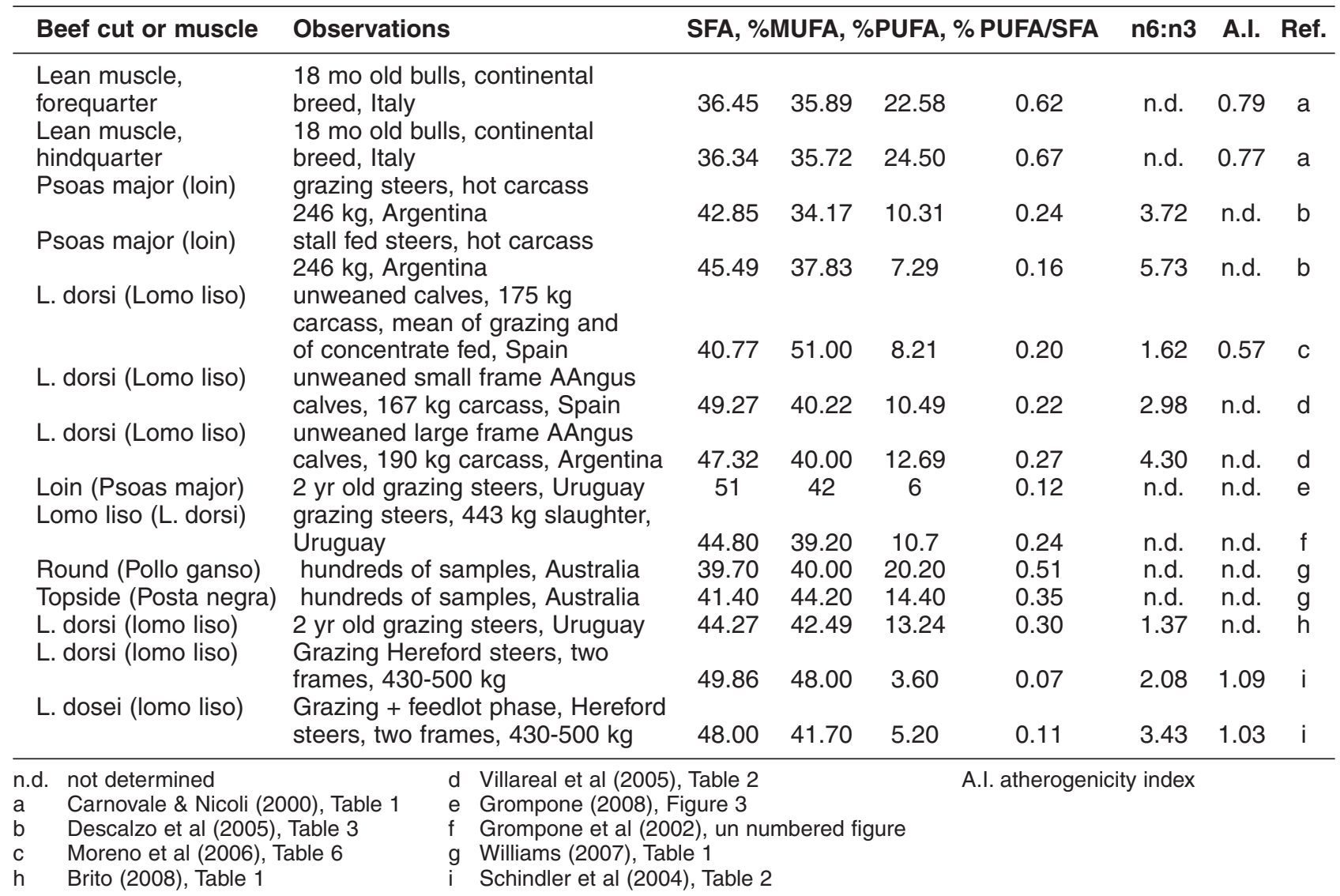

2008). In this context, it would be of interest in future studies to assess the proportion of vaccenic acid (C18:1 trans 11), a direct precursor of CLA, and presumably present in the C18:1t fraction shown in Table 1 (Grompone, 2008) since Nudda et al. (2008) have shown in goats that the contents of these fatty acids in milk is closely correlated with those found in kids' muscles. Furthermore, monounsaturated fatty acids such a oleic acid have shown positive attributes in terms of human health, including antiapoptotic effects and others (e.g. Maedler et al., 2003; Bauman et al., 2008). The contribution of trans fatty acids to the total fat content was extremely small in comparison to data for several European countries reported by Aro et al., (1998).

The atherogenicity index proposed by Ulbricht and Southgate (1991) integrates undesirable and desirable fatty acids from a human health perspective, and as shown in Table 2 all cuts showed low values, notwithstanding significant differences between them. The actual contents of individual fatty acids (Table 3 ) are useful in computing potential intake by human subjects.

In this case, as well as for the rest of the parameters quantified, "lomo liso" is notoriously different from the remaining cuts, but it still possesses a very desirable lipid profile. All cuts examined in the present analyses were leaner and had slightly better lipid composition than that of the older steers most frequently reported in the literature. Despite the higher fat content and the fatty acid profile of the samples analyzed by Enser et al. (1996) who found up to $15.5 \%$ fat, a PUFA/SFA ratio of 0.11 and $n 6: n 3$ ratio of 2.1 , the authors concluded that they constituted a valuable source of unsaturated fatty acids and that the PUFA/SFA ratio of 0.11 did not constitute a significant disadvantage in the context of a well balanced human diet. That would certainly be the case for the beef cuts examined in this paper.

\section{CONCLUSIONS}

This study demonstrated that important differences exist in the fat content and the fatty acid profile of eight different cuts obtained from suckling male and female beef calves 7-8 months old. Nevertheless, all the cuts were lean, relatively low in saturated fatty acids, had a healthy n6:n3 ratio and a low atherogenicity index, and generally had adequate lipid composition. Furthermore, these meat cuts were comparable in terms of lipid composition to the best cuts produced in grazing systems by traditional beef exporting countries. 
They would thus make a valuable contribution to a balanced human diet. The relationship between the composition and intake of the dam's milk, and the calves' body composition remains to be elucidated. A discriminant analysis based solely on the percentage of the fatty acids, classified samples belonging to different cuts with reasonable accuracy but further confirmation of the accuracy of these statistical analyses would be desirable if they are to be used for trace ability and quality control purposes.

\section{ACKNOWLEDGEMENTS}

The present research was carried out between 2006 and 2010, Project Code FIA-PI-T-2006-1-P039, and was financed by Fundación para la Innovación Agraria (FIA) of the Ministerio de Agricultura de Chile.

\section{REFERENCES}

AOAC. 2005. AOAC Official Method 996.06. Fat (Total, Saturated, and Unsaturated) in Foods AOAC International.

Aro A, Antoine JM, Pizzoferrato L, Reykdal O, van Poppel G. 1998. Trans fatty acids in dairy and meat products from 14 European countries: the TRANSFAIR study. J. Food Comp An 11, 150-160.

Aurousseau B, Bauchart D, Galot AL, Prache S, Micol D, Priolo A. 2007. Indoor fattening of lambs raised on pasture: 2. Influence of stall finishing duration on triglyceride and phospholipid fatty acids in the longissiumus thoracis muscle. Meat Sci. 76, 417-427.

Bauman DE, Perfield II JW, Harvatine KJ, Baumgard LH. 2008. Regulation of fat synthesis by conjugated linoleic acid: lactation and the ruminant model. J. Nutr. 138, 403-409.

Bligh EG, Dyer WJ. 1959. A rapid method of total lipid extraction and purification. Can J. Biochem. Physiol. 37, 911-917.

Boyazoglu J, Morand-Fehr P. 2001. Mediterranean dairy sheep and goat products and their quality. A critical review. Small Ruminant Res. 40, 1-11.

Brito, G. 2008. Diferenciación de las carnes bovinas del Uruguay a partir de sus atributos intrínsecos y su influencia en la salud humana y conservación del producto. Seminario Internacional "Enfoques sobre la calidad de carne y grasa en rumiantes", Garibotto, G. and G. Bianchi, eds. Paysandú, Uruguay: Universidad de la República, p. 1-19.

Carnovale E, Nicoli S. 2000. Changes in fatty acid composition in beef in Italy. J. Food Comp. Anal. 13, 505-510.

Christie WM. 1989. Gas chromatography and lipids. A practical guide. The Oily Press, Bridgwater.

Christie WM, Dobson G, Adlof RO. 2007. A practical guide to the isolation, analysis and identification of conjugated linoleic acic. Lipids 42, 1073-1084.

Descalzo AM, Insani EM, Biolatto A, Sancho AM, García PT, Pensel NA, Josifovich JA. 2005. Influence of pasture or grain-based diets supplemented with vitamin $E$ on antioxidant/oxidative balance of Argentine beef. Meat Sci. 70, 35-44.
Enser M, Hallet KG, Hewett B, Fursey GA, Wood JD. 1996. Fatty acid content and composition of English beef, lamb and pork at retail. Meat Sci. 42, 443-456.

Garibotto G, Bianchi-Olascoaga G, eds. 2008. Enfoque sobre la Calidad de Carne y Grasa en Rumiantes: El consumidor como Prioridad. Seminario Técnico Internacional, Facultad de Agronomia, Universidad de la República Oriental del Uruguay, Paysandú.

Grompone MA, Pagano T, Gayoso V, Taroco L. 2002. Grasa buena y grasa mala: Efecto del genotipo en el contenido y composición lipídica de la carne vacuna. In Cruzamientos en Bovinos para Carnes, INIA, Tacuarembó, Uruguay, p. 81-85.

Grompone MA. 2008. Lípidos de la carne vacuna y sus propiedades nutricionales. Seminario Internacional "Enfoques sobre la calidad de carne y grasa en rumiantes", Garibotto G, Bianchi G, eds. Paysandú, Uruguay: Universidad de la República, p. 66-76.

Kraft J, Kramer JKG, Schoene F, Chambers JR, Jahreis G. 2008. Extensive analysis of long-chain polyunsaturated fatty acids, CLA, trans-18:1 isomers, and plasmalogenic lipids in different retail beef types. J. Agric. Food Chem. 56, 4775-4782.

Latimori NJ, Kloster AM, Amigone MA, García PT, Carduza FJ, Pensel NA. 2005. Calidad de la carne bovina según genotipo y sistema de alimentación. 28을 Congreso Argentino de Producción Animal, Bahía Blanca, Argentina, p. TPP7.

Lichtenstein AH. 2006. Dietary fat, carbohydrate, and protein: effects on plasma lipoprotein patterns. J. Lipid Res. 47, 1661-1667.

Maedler K, Oberholtzer L, Bucher J, Spinas GA, Donath MY. 2003. Monounsatured fatty acids prevent the deleterious effects of palmitate and high glucose on human pancreatic B-cell turnover and function. Diabetes 52, 726-733.

Montossi F, Brito G, San Julián R, Luzardo S, del Campo M, Vaz Martins D, La Manna A, Sañudo C. 2008. Diferenciación y valorización de la carne ovina y bovina del Uruguay en Europa. Rev. INIA (Uruguay) (14) 2-7.

Moreno T, Varela A, Oliete B, Carballo JA, Sánchez L, Montserrat L. 2006. Nutritional characteristics of veal f rom weaned and unweaned calves: discriminatory ability of the fat profile. Meat Sci. 73, 209-217.

Nudda A, Palmquist DL, Battacone G, Francellu S, Rassu SPG, Pulina G. 2008. Relationships between the contents of vaccenic acid, CLA, and n-3 fatty acids of goat milk and the muscle of their suckling kids. Livest Sci. 118, 195-203.

Pacheco YM, Bermúdez B, López S, Abia R, Villar J, Muriana FJG. 2006. Ratio of oleic to palmitic acid is a dietary determinant of thrombogenic and fibrinolytic factors during the postprandial state in men. Am. J. Clin. Nutr. 84, 342-349.

Poveda JM, Cabezas L. 2006. Free fatty acid composition of regionally-produced Spanish goat cheese and relationship with sensory characteristics. Food Chem. 95, 307-311.

Prache S, Cornu A, Berdagué JL, Priolo A. 2005. Traceability of animal feeding diet in the meat and milk of small ruminants. Small Rum Res. 59, 157-168.

Rearte D. 2002. Calidad de carne en sistemas pastoriles. Rev. IDIA (Argentina) (21) 13-18.

Reid LM, O'Donnell CP, Downey G. 2006. Recent technological advances for the determination of food authenticity. Trends Food Sci. Tech. 17, 344-353.

Sañudo C, Sierra I, Olleta JL, Martín L, Campo M, Santolaria P, Wood JD, Nute GR. 1998. Influence of 
weaning on carcass quality, fatty acid composition and meat quality in intensive lamb production systems. Anim. Sci. 66, 175-187.

Schindler V, Kedzierski M, Pruzzo L, Santa-Coloma LFD. 2004. Efecto del sistema de alimentación sobre ácidos grasos, grasa intramuscular y colesterol en reses de novillos Hereford. Rev. Fac Agron UBA (Argentina) 24, 147-153.

Scollan N, Richardson I, De Smet S, Moloney AP, Doreau M, Bauchart D, Nuernberg K. 2005.

Enhancing the content of beneficial fatty acids in beef and consequences for meat quality. In J. F. Hocquette and S. Gigli, (eds.) Indicators of milk and beef quality. Wageningen Academic Publishers, Wageningen, $\mathrm{p}$ 151-162.

Scollan N, Hocquette JF, Nuernberg K, Dannerberger D, Richardson I, Moloney A. 2006. Innovations in beef production systems that enhance the nutritional and health value of beef lipids and their relationship with meat quality. Meat Sci. 74, 17-33.
Ulbricht TL, Southgate DA. 1991. Coronary heart disease: seven dietary factors. Lancet 338, 85-992.

Vera RR, English P, Vargas P. 2009. Carne bovina de primera calidad. El producto de una asociación de pequeños productores de la VII Region. Rev. FAIF (Chile) 36, 18-21.

Villareal E, Faverin C, Santini F, Paván E, Depetris G, Schor A, Naón JJ. 2005. Evaluación postdestete de características de carcasa y de la carne en terneros de distintos biotipos. 28ㅇ Congreso Argentino de Producción Animal, Bahía Blanca, Argentina, p. TPP7.

Williams PG. 2007. Nutritional composition of red meat. Nutr Dietetics 64, S113-S119.

Wood JD, Enser M, Fisher AV, Nute GR, Sheard PR, Richardson RI, Hughes SI, Whittington FM. 2008. Fat deposition, fatty acid composition and meat quality: a review. Meat Sci. 78, 343-358.

Recibido: $11 / 3 / 09$ Aceptado:13/4/09 